ИЗВЕСТИЯ АКАДЕМИИ НАУК ЭСТОНСКОИ ССР. ТОМ 32. ГЕОЛОГИЯ. 1983, № 2

\title{
ДОЛОМИТЫ В ВЯОСКОЙ СВИТЕ СРЕДНЕГО ОРДОВИКА ЭСТОНии
}

Крепкие толстослоистые известняки вяоской свиты используются для изготовления щебня (карьеры Вяо, Харку, Маарду) и как цементное сырье («Пунане Кунда»). В окрестностях Таллина с давних времен добывают строительный известняк, из которого сооружены многие здания города. Строительный камень добывали в начале из естественной стены (глинта) Ласнамяэ, а потом из каменоломен Ласнамяэ, Кадака и Харку. В стенах разных построек среди серых известняков очень часто встречаются бурые доломиты, которые придают пестрый вид стенам зданий. В Северо-Западной Эстонии доломитизировано приблизительно $5-10 \%$ пород вяоской свиты. Почти повсеместно встречающаяся доломитизация (рис. 1) усложняет разведку известняков на цементное сырье, поскольку высокое содержание магния снижает качество продукции. Вяоская свита имеет мощность от 2,9 (Калана 393) до 14,4 м (Выру). Мощность ее уменьшается в северо-западном направлении. Вяоская свита залегает от 1 до 46 м выше нижней границы карбонатных пород ордовика (рис. 1), ниже которых распространяются терригенные породы

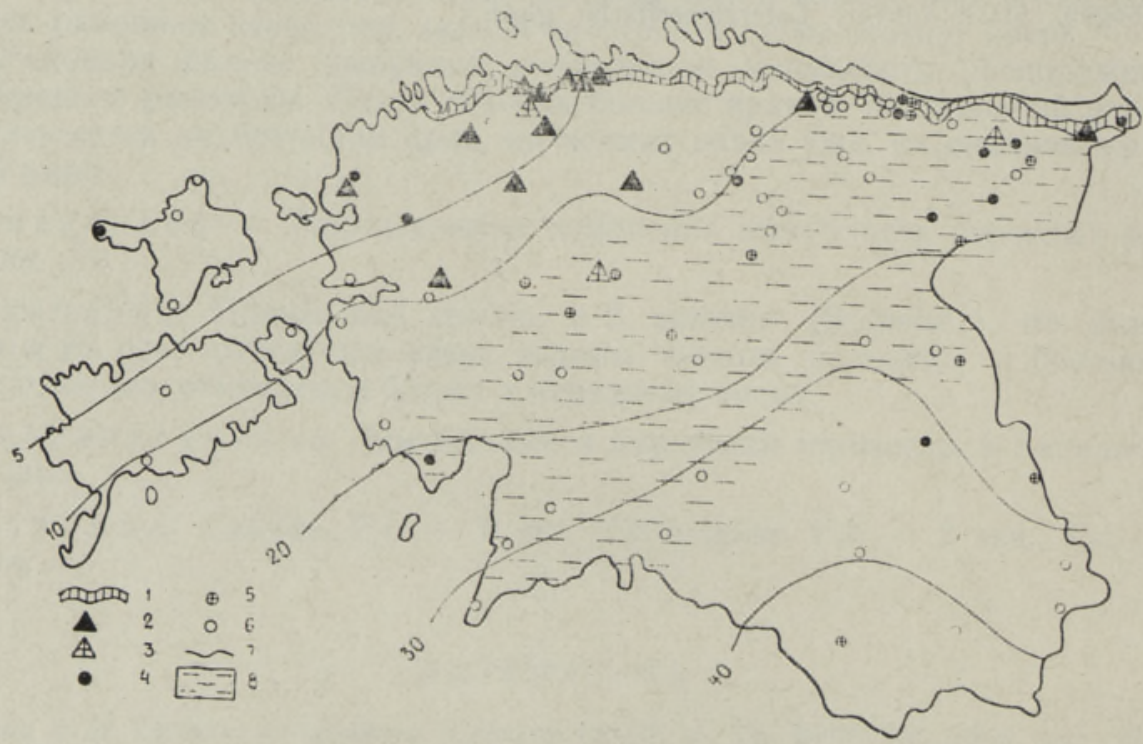

Рис. 1. Распространение доломитов в вяоской свите Эстонии. 1 - выход вяоской свиты; 2 - доломит с расширенной решеткой по рентгеноструктурному анализу; 3 - доломит с идеальной структурой по рентгеноструктурному анализу; 4 - доломит с расширенной решеткой по химическому анализу; 5 - доломит с идеальной структурой по химнческому анализу; 6 - скважины, в которых по химическим анализам доломит не найден; 7 - изолинии мощности карбонатных пород ниже вяоской свиты; 8 - зона метасоматической доломитизации (Пичугин и др., 1976). Доломитизация отмечена в случае, если хотя бы одна проба оказалась доломитом. 
нижнего ордовика и кембрия, которые могли служить свободно движущимся подземным водам путями привноса магния для доломитизации.

K. Орвику расчленил ласнамягиский горизонт (соответствующий по объему нынешней вяоской свите) на три части: нижний мергелистый известняк, средний доломитовый слой (мощностью $40 \mathrm{~cm}$ ), верхний крепкий известняк (Orviku, 1940). Такое же расчленение принято в стратиграфической схеме 1976 г. (Решения..., 1978) (см. табл. 1).

Таблица 1

\begin{tabular}{|c|c|c|c|c|c|}
\hline \multicolumn{2}{|c|}{ К. Орвику, 1940} & \multicolumn{4}{|c|}{ Стратиграфическая схема, 1976} \\
\hline \multirow{3}{*}{ 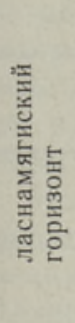 } & $\begin{array}{l}\text { крепкий } \\
\text { известняк }\end{array}$ & $\begin{array}{l}\text { Нижний подгоризонт } \\
\text { ухакуского горизонта }\end{array}$ & \multirow{3}{*}{ 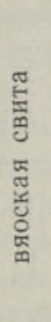 } & \multicolumn{2}{|c|}{$\begin{array}{c}\text { костивереская } \\
\text { пачка }\end{array}$} \\
\hline & $\begin{array}{l}\text { доломитовый } \\
\text { слой }\end{array}$ & \multirow{2}{*}{$\begin{array}{l}\text { ласнамягиский } \\
\text { горизонт }\end{array}$} & & паэская & пачка \\
\hline & $\begin{array}{l}\text { мергелистый } \\
\text { известняк }\end{array}$ & & & \multicolumn{2}{|c|}{$\begin{array}{c}\text { ребалаская } \\
\text { пачка }\end{array}$} \\
\hline
\end{tabular}

Известняки вяоской свиты светло-серые, средне-до толстослоистые. Слои известняков разделены прослойками мергеля мощностью $1-3$ мм. Химический состав пород приведен в табл. 2. Преобладает илисто-зернистая структура - $60-70 \%$ скрытокристаллической основной массы, 20-40\% детрита иглокожих, трилобитов, брахиопод, моллюсков и др. (фототаблица I, фото 4). В Северо-Западной Эстонии доломиты кавернозные и пористые темно-серые или буроватые, в Северо-Восточной и Средней Эстонии встречаются и светло-серые разновидности. В зонах трещиноватости они иногда пятнами приобретают фиолетовый или красный цвет. Кристаллы доломита величиной $0,1-0,3$ мм образуют мозаичную структуру (фототаблица I, фото 3), в которой нередко встречаются реликты детрита нормально морских организмов.

К. Орвику описал кроме доломитового слоя, который он считал на основании широкого площадного распространения диагенетическим, и локальную доломитизацию, встречающуюся в Северо-Восточной, а местами и в Северо-Западной Әстонии особенно в мергелистом известняке, реже в верхнем крепком известняке. Локальные тела доломита (по мнению К. Орвику) образовались уже в твердой породе после диагенеза осадка. В шлифах доломит из доломитового слоя по структуре не отличается от доломита из локальных тел нижней части вяоской свиты Северо-Западной Әстонии (Orviku, 1940). Химический состав и характер кристаллической решетки также одинаковые (табл. 2 и 3 ; химические анализы проведены в лаборатории Управления геологии ЭССР, рентгеноструктурный анализ - в лаборатории Тартуского государственного университета К. Утсалом). По данным рентгеноструктурного анализа эти доломиты имеют расширенную решетку (межплоскостное расстояние $2,899-2,905 \AA$ ) по сравнению с нормальным доломитом $(2,885 \AA)$. По пересчетам результатов химических анализов выяснилось, что в доломитах содержится около 10 вес. \% избыточного $\mathrm{CaCO}_{3}$. Поскольку рентгеноструктурным анализом кальцит не обнаружен, можно предполагать, что избыточный кальций находится изоморфно в структуре минерала доломита и в связи с более крупными размерами по сравнению с ионом магния расширяет кристаллическую решетку (Вингисаар, Утсал, 1978). По спектральным и химическим анализам в этих доломитах обнаружены повышенные содержания железа и марганца 


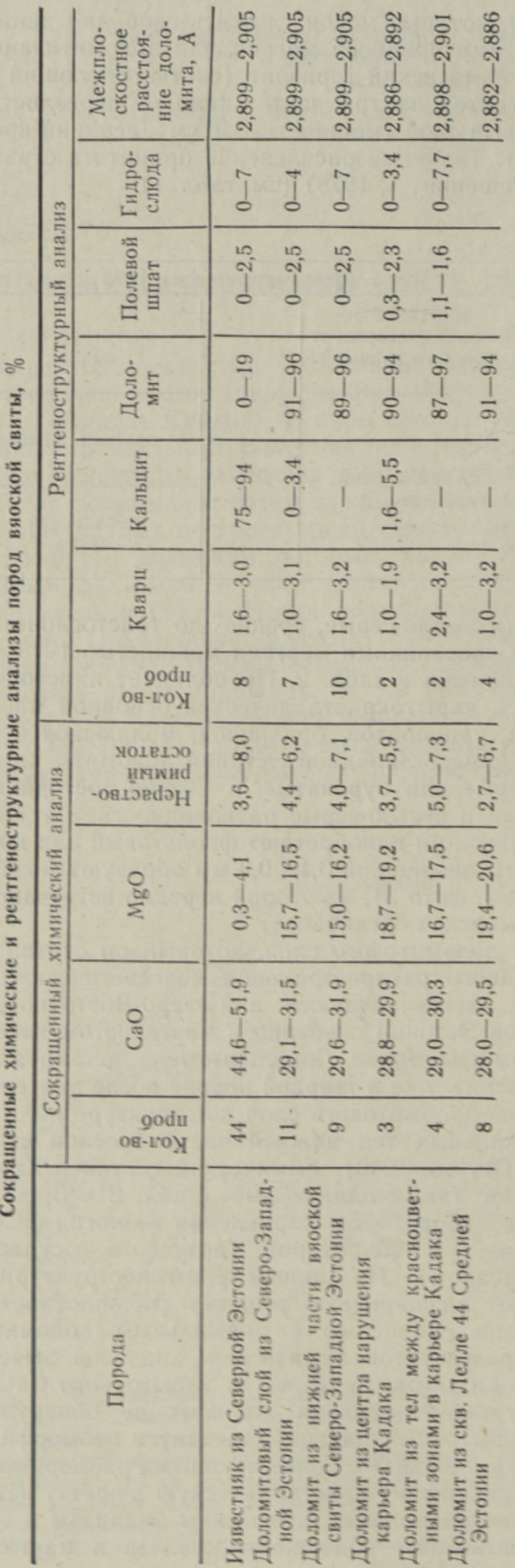

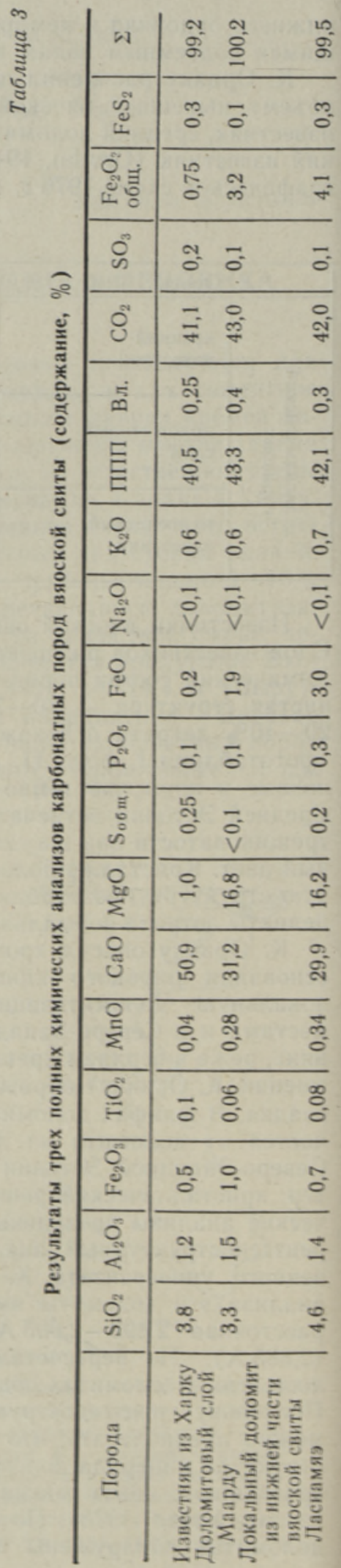


( $\mathrm{Fe}_{2} \mathrm{O}_{3}$ общ. 2,5-4,5\%, Mn $0,2-0,6 \%$ ) по сравнению со средним содержанием в доломитах Эстонии $\left(\mathrm{Fe}_{2} \mathrm{O}_{3}\right.$ общ. $\left.1,7 \% ; \mathrm{Mn} 0,16 \%\right)$ и в известняках вяоской свиты $\left(\mathrm{Fe}_{2} \mathrm{O}_{3}\right.$ общ. $\left.1,3 \% ; \mathrm{Mn} 0,21 \%\right)$.

Доломиты с идеальной кристаллической структурой найдены в основном в Пярну-Наровской зоне тектонической трещиноватости и по берегу Чудского озера (рис. 1), в Северо-Западной Эстонии они встречаются редко. В случае нахождения доломита с идеальной структурой обычно доломитизировано и большинство выше- и нижележащих горизонтов. Доломиты, секущие весь разрез карбонатных пород Эстонии, детально описаны (Вахер и др., 1961; Пичугин и др., 1976), поэтому в настоящей статье основное внимание обращается на доломиты вяоской свиты, где минерал доломит имеет расширенную кристаллическую структуру. Доломиты с расширенной кристаллической структурой встречаются в основном в Северной, особенно в Северо-Западной Эстонии, реже в перечисленных областях распространения доломита с идеальной структурой.

Морфология тел доломитизированных пород, содержащих минерал с расширенной решеткой, т. е. доломитового слоя и тел локальной доломитизации в карьерах окрестности Таллина довольно своеобразная. Ранее подчеркнутое прямое пространственное совпадение доломитизации с зонами трещиноватости (Вахер и др., 1961) действительно только в общих чертах. В последние годы в Таллине раскрыты зоны трещиноватости и доломитизации северо-восточного направления в траншее для железной дороги, которая пересекает глинт в старой каменоломне Кадака, и в траншее в новом жилом районе Ласнамяэ. В этих обнажениях четко выявляется закономерность, что непосредственно к главным трещинам примыкают не доломиты, а известняки. Доломитизация начинается на расстоянии от нескольких десятков сантиметров до нескольких метров өт трещин (рис. 2). Известняки непосредственно у трещин не являются результатом дедоломитизации - они не отличаются от нормальных неизменных известняков - сохранились первичная детритовая структура и слоистость. Очевидно, что во время доломитизации уже существовали эти трещины северо-восточного до широтного направления - преобладающие азимуты $40-50^{\circ}$. Трещины криволинейные (фототаблица II, фото 3), с бугорчатыми поверхностями, содержат кальцит I генерации, пирит и сфалерит. Вторая группа трещин с заполнениями кальцита более поздних генераций, а также пустые прямолинейные трещины (азимутом $125^{\circ}$ ) пересекают доломиты без влияния на их морфологию, следовательно, они образовались после доломитизации (рис. 3 $Б, B$; фототаблица I, фото 1 и 2). Э. Мёлс исследовал детально трещиноватость в каменоломне Ласнамяэ и выделил несколько стадий раскрытия и соответствующие генерации минералов в трещинах (Möls, 1960; Niin и др., 1981). По исследованиям автора, доломитизация произошла ло образования молочно-белого кальцита II генерации, выделенного Э. Мёлсом.

В карьере Кадака имеется зона трещиноватости с более сложным сочетанием вторичных изменений (рис. 2). Установленные вертикальные зоны красноцветных известняков шириной $1-10$ м тесно связаны некоторыми трещинами. Между красноцветными зонами располагаются тела локальной доломитизации. Кристаллическая решетка минерала доломита в этих породах расширенная (табл. 2).

Доломиты отделяет от красноцветных известняков зона неизмененных сероцветных известняков шириной $1-3$ м. Доломитизации в азериском горизонте не встречается. В центре главной красноцветной зоны имеется пликативный изгиб слоев амплитудой 30 см. На том же месте находится трещина с заполнением кальцита, пирита и сфалерита. По стенкам трещины и около 20 см в обе стороны найден доломит второй генерации. Минерал доломит здесь имеет идеальную кристаллическую 

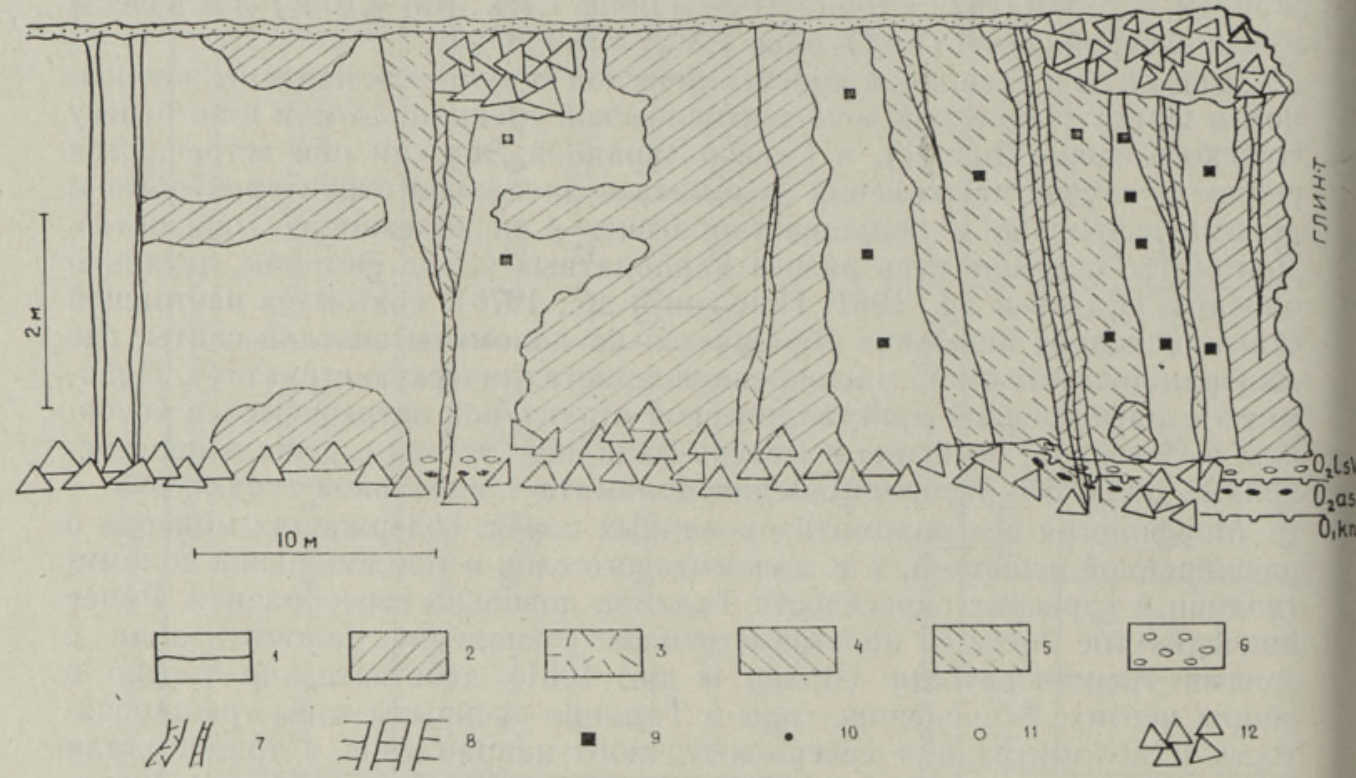

Рис. 2. Разрез зоны трещиноватости и вторичных изменений в карьере Кадака. Условные обозначения к рис. 2 и $3: 1$ - известняк; 2 - доломит; 3 - заполнения трещин; 4 - доломит в жилах; 5 - красноцветность; 6 -оолиты; 7 - трещины с заполнениями кальцита; 8 - пустые трещины; 9 - пирит; $10-$ сфалерит; 11 - точки опробования; 12 - обломки пород.

структуру и в отличие от вышеописанного образует в кавернах и по стенкам трещины друзы с кристаллами до 3 мм. В карьере Кадака в заполнении трещины между I и II генерациями кальцита найдены кристаллы доломита (рис. $3, \Gamma$ ). В красноцветных известняках обнаружены псевдоморфозы гематита по пириту. В трещинах развивается также галенит.

Трудно твердо установить последовательность вторичных процессов в карьере Кадака. Ясно, что после образования первых трещин произошла пиритизация, а красноцветность появилась позже. В начальных стадиях вторичных процессов образовались еще калыци I генерации и обе генерации доломита. Все это было закончено до образования второй, третьей и четвертой генераций кальцита. Позже образовались прямолинейные пустые трещины. Нет сомнения, что локальная доломитизация, описанная в вяоской свите, - вторичная, поскольку тела пространственно связаны ранней тектонической трещиноватостью и их границы рассекают вертикально на 2-4 м первичную слоистость известняков (рис. 2). Кроме того, доломитизация ограничивается в основном вяоской свитой и редко распространяется в вышележащие более глинистые известняки кыргекаллаской свиты и нижележащие оолитовые извест-

\section{ФОТОТАБЛИЦА I}

Фото 1. Вертикальная трещина пересекает доломитовый слой (оконтурен белой линией), не имея влияния на его морфологию - образование трещины произошло после доломитизацин. Ласнамяэ.

Фото 2. Заполнение трещины кальцитом и сульфидами. Ласнамяэ.

Фото. 3. Доломит. Ннколы скрещены, скв. Ласнамяэ, гл. 10,0 м; $40 \times$.

Фото 4. Детритовый известняк. Скв. Ласнамяэ, гл. 5,3 м; $40 \times$. 

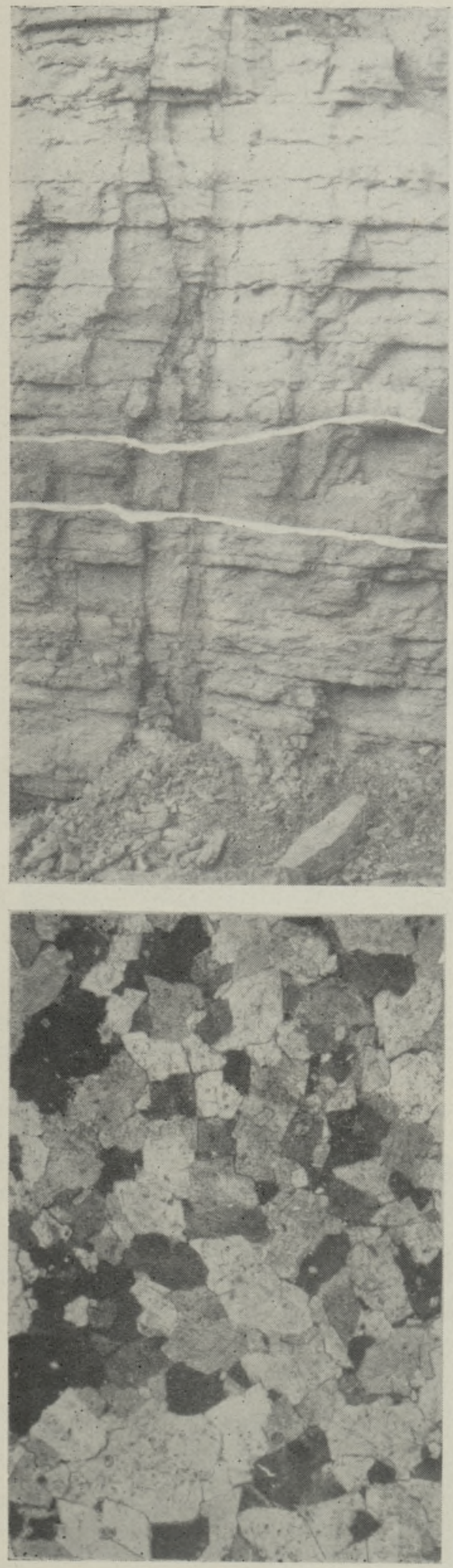
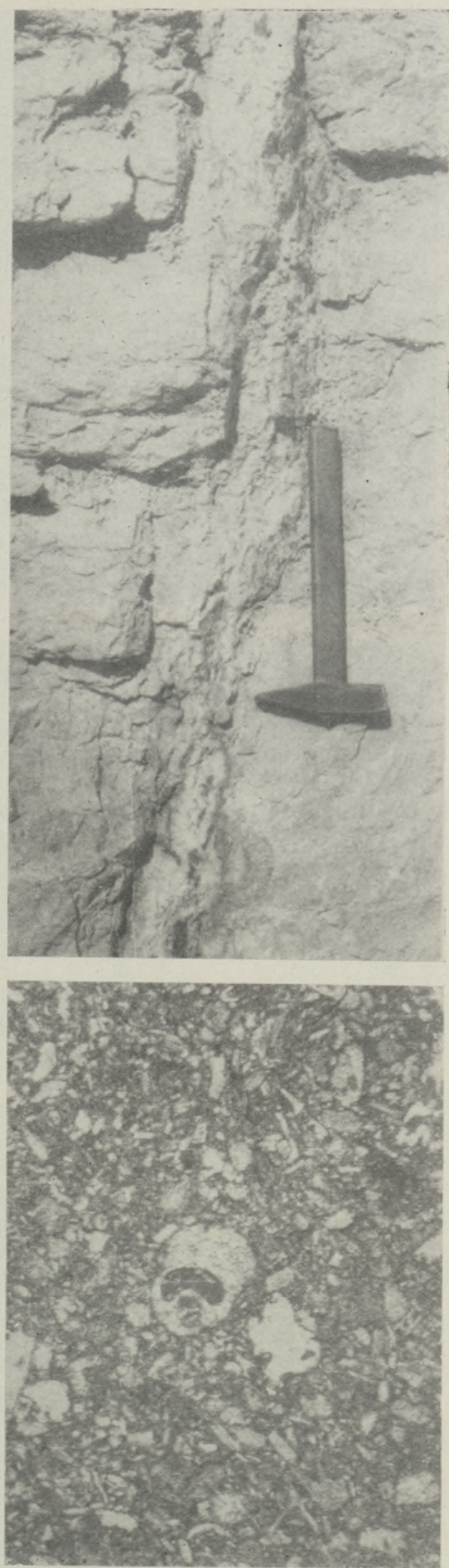
ФОТОТАБЛИЦА ІІ
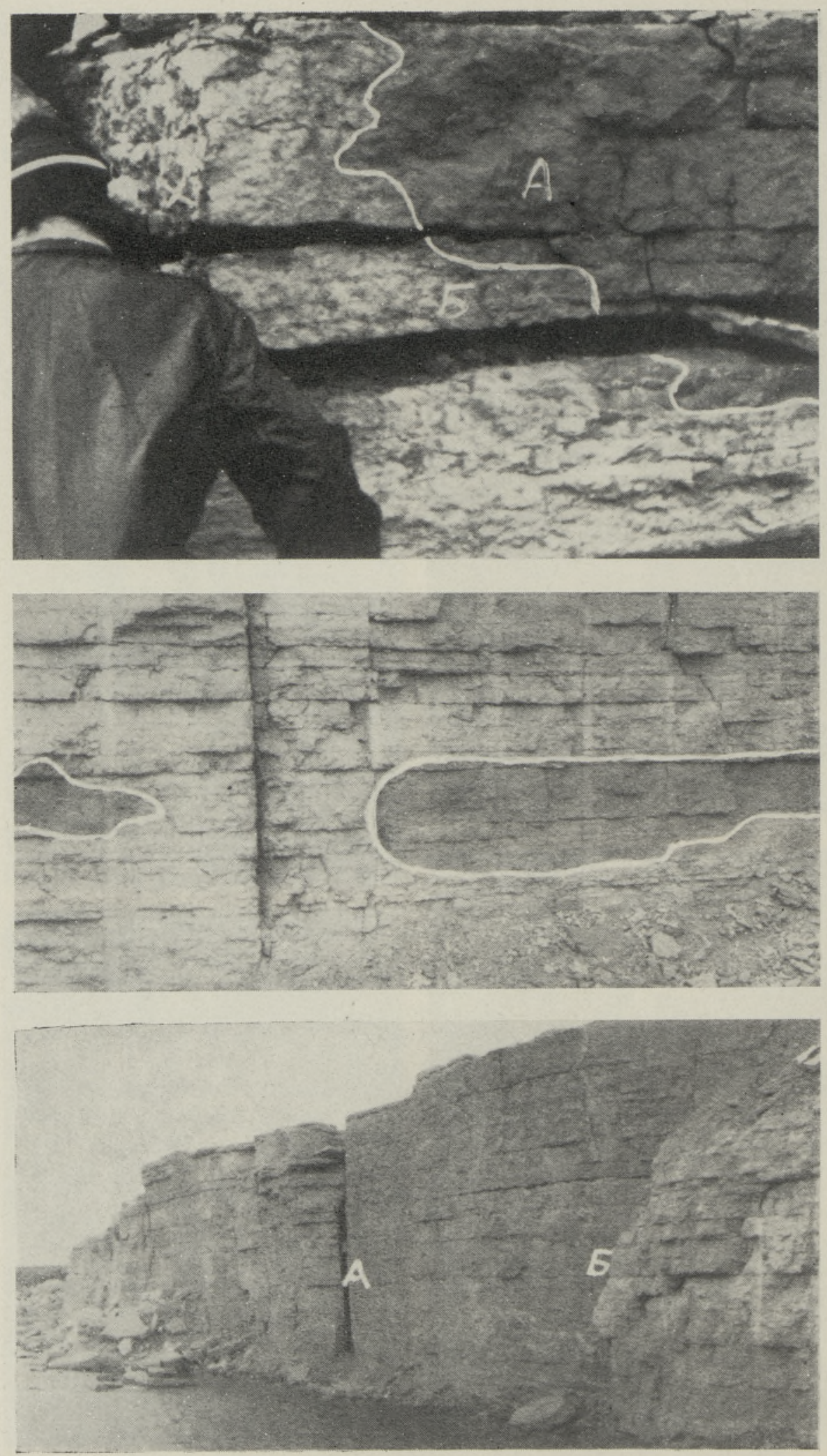


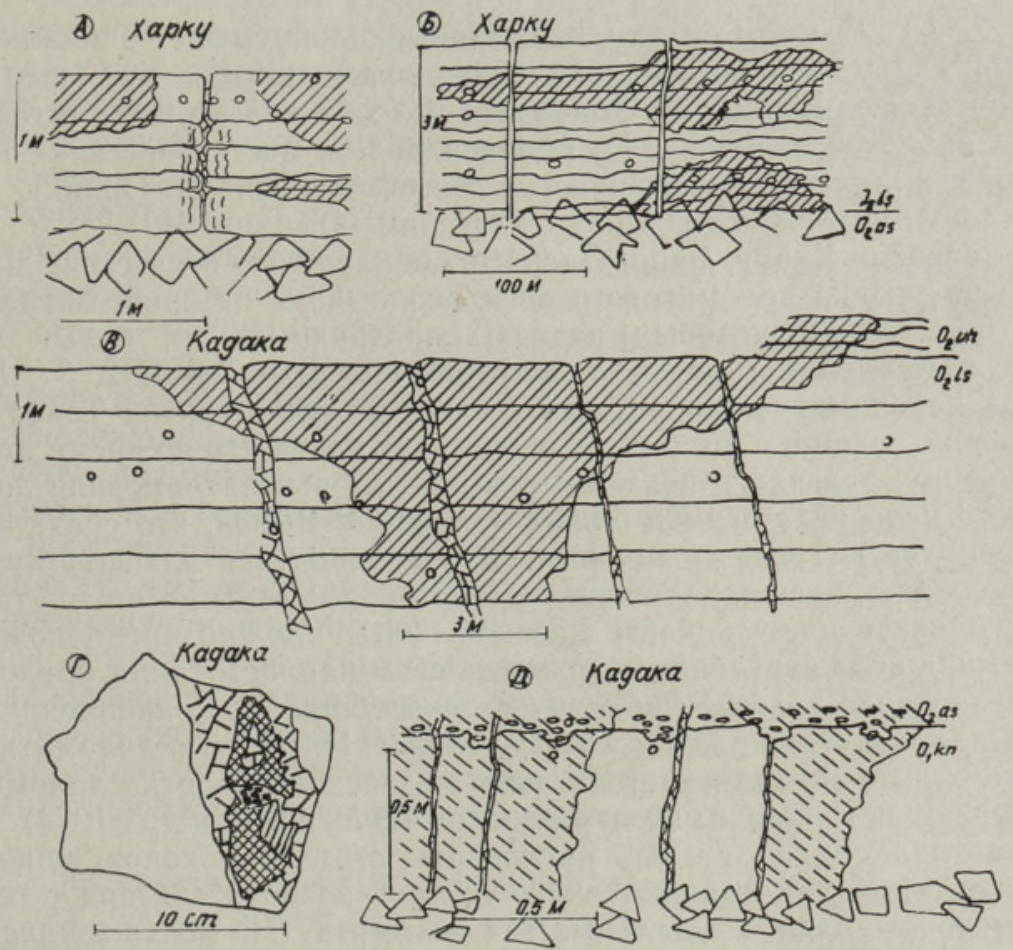

Рис. 3. Морфология доломитизации и красноцветности в карьерах Харку и Кадака. $A$ - доломитовый слой прерывается около трещины; $E$ - мощность доломитового слоя изменяется при отчетливо выдержанной первичной слонстости. Пустые трещины пересекают доломиты, не имея влияния на их морфологию; $B$ - трещины с заполнениями кальцита II и III генераций пересекают тело доломита, не влияя на его морфологию; $\Gamma$ - жила кальцита в известняке с дробленным куском доломита и кристаллами доломита между I и II генерациями кальцита; Д - характер распространения красноцветности.

няки кандлеской свиты (из последних чаще доломитизированы верхние слои с белыми оолитами).

Время доломитизации, связанной с зонами трещиноватости северовосточного направления, считают додевонским (Вингисаар и др., 1974; Пичугин и др. 1976) и связывают с завершением тектонических процессов в соседней каледонской геосинклинали. Это хорошо согласуется с данными о связи доломитизации с наиболее ранними трещинами.

В стенах карьеров на протяжении нескольких сот метров обнаруживаются колебания мощности горизонтального доломитового слоя в пределах 0-70 см при строго выдержанной мощности первичных слоев

\section{ФОТОТАБЛИЦА ІІ}

Фото 1. Карьер Харку. Около трещины отсутствует доломитизация, на уровне доломитового слоя, выделенного К. Орвику. Белой линией отмечена граница доломитизации: более темный - доломит (А), светлая порода вблизи трещины - детритовый известняк с некоторыми пятнами доломитизации (Б). Фото В. Таалманн.

Фото 2. Траншея в жилом районе Ласнамяэ. Доломитовый слой прерывается 0,5-1 м по обе стороны от трешины. Вблизи трещины встречается нензмененный детритовый известняк - доломнтизация отсутствует. Белой линией оконтурен доломит. Фото 3. Поверхность трещины $(\mathrm{A}-\mathrm{D})$ обнажается на уступе Ласнамяэ. Заслуживает внимания волнистый характер трещины. 
(рис. 3, Б). В местах, где доломитовый слой толще, в нижней части вяоской свиты, появляется локальная доломитизация, что указывает на генетическое единство этих доломитов. Следовательно, доломитовый слой также является вторичным и образовался за счет известняка в стадии катагенеза. Этот вывод отличается от точки зрения К. Орвику, который считал доломитовый слой диагенетическим (Orviku, 1940).

В карьерах Харку, Вяо и Ласнамяэ обнаружено отсутствие доломитизации на уровне доломитового слоя около 0,5 м от криволинейных трещин, по стенкам которых развиты прозрачный или белый кальшит. пирит и сфалерит (рис. $3, A$, фототаблица II, фото $1,2,3$ ). Никаких следов дедоломитизации вблизи трещин не обнаружено. Такое взаимоотношение трещин с доломитом указывает на то, что во время доломитизации в них двигались попземные воды, которые затормозили доломитизацию в непосредственной близости трещин. Вывод, что среда свободно движущихся подземных вод была неблагоприятной для доломитизации, подтверждается еще наличием пятнистой доломитизащии внутри слоев известняков в нижней части вяоской свиты. Можно предположить, что подземная вода двигалась по поверхностям напластования, предотвращала образование доломита вблизи их и способствовала накоплению магния внутри слоев, где движение вод мелленнее. Пятнистую доломитизацию в вяоской свите считали диагенетической, поскольку пятна доломита прослеживают вертикальные ходы илюелов (Вингисаар и др., 1974). По мнению автора данной статьи, внутренняя структура ходов илоедов способствовала доломитизации внутри ходов, котопая связана с генезисом доломитового слоя и локальных тел поломита. Это подтверждается одинаковой структурой в шлифах лоломита всех перечисленных типов, а также наблюдаемой в обнажениях тенденцией к интенсивной пятнистой долюмитизации вблизи долпмитового глоя.

Доломитовый слой развивается непосредственно выше контакта нижних среднеслоистых слабо глинистых известняков с верхними толстослоистыми относительно чистыми известняками (фототаблица II, фото 2 и фототаблица I, фото 1). Возможно, что толстослоистые, во время доломитизации с редкой трещиноватостью известняки, служили экраном для магнезиальных подземных вод, которые поднимались вверх из нижележаших песчаников и алевролитов нижнего ордовика и кембрия.

Исследования гидрогеологов показали, что движение подземных вод происходит особенно интенсивно по контактам глинистых и более чистых карбонатных пород, а чистые толстослоистые известняки практически сухие (Перенс, 1978). Можно предполагать, что такой же характер движения растворов частично объясняет вышеописанные особенности морфологии доломитовых тел и слоя. Подземные воды двигались по трещинам и контакту ннжней и верхней частей свиты. Доломитизация развивалась непосредственно выше контакта, где свободное движение вод было заторможено. Очевидно, доломитизация происходила под влиянием диффузии вещества в капиллярах породы. С. Г. Вишняков считает, что интенсивное движение подземных вод не может создать доломитизащию, а оказывает только растворяющее действие. Доломитизащия происходит при медленном движении подземных вод (Вишняков, 1956). Такое мнение хорошо согласуется с вышеописанными морфологическими особенностями доломитовых тел и слоя.

О гидрохимии доломитосаждающих подземных вод можно делать только предположення. Повышенное содержание двухвалентного карбонатного железа в доломите (табл. 3) свидетельствует о нейтральной среде $(\mathrm{Eh} \approx 0)$, в которой железо способно мигрировать. Әто согласуется с данными о гидрохимии вод озер Юго-Восточной Австралии, где происходит современное осаждение доломита (Borch, 1965). Одним из основных факторов, определяющих осаждение доломита, является соот- 
ношение $\mathrm{Mg} / \mathrm{Ca}$ в растворе (Lovering, 1969; Folk и др., 1975). Для доломитообразования при низких температурах требуется преобладание магния над кальцием. Основным недостатком теории доломитизации под действием подземных вод считают небольшое содержание магния в ббольшинстве подземных вод и преобладание кальция над магнием (Страхов, 1956). Главным источником магния считают морскую воду, где молярное отношение $\mathrm{Mg} / \mathrm{Ca}=5,2-5,3$.

В конечной стадии каледонской геосйнклинали, когда на западе образовались горные цепи и произошло общее поднятие территории с формированием артезианских бассейнов, возможно, что в Эстонии началась разгрузка реликтовых морских вод из нижележащих терригенных отложений, которые могли быть источником магния для вторичной доломитизации вышележащих пород.

Процессу доломитизации способствует повышенная температура. Г. Э. Усдовский сопоставил анализы около 400 проб подземных вод с фазовой диаграммой кальцита, доломита и магнезита в растворе и пришел к выводу, что при температуре $80^{\circ} \mathrm{C} 87 \%$ подземных вод в контакте с известняком формируют доломит (Usdowski, 1968). В ПярнуНаровской зоне тектонических нарушений, где широко развиты доломиты с идеальной кристаллической структурой, часто встречаются проявления сульфидной минерализации (Судов, 1973), которые указывают на гидротермальные процессы. Возможно, что повышенная температура обусловила доломитообразование на этой территории (Пичугин и др.,
1976 ).

Исходя из кристаллической структуры минерала, морфологии доломитовых тел, слоя и пятен, их взаимоотношений с трещинами, а возможно, и генезиса, в вяоской свите выделяются доломиты двух типов.

I тип содержит минерал доломит с расширенной кристаллической структурой. Доломитизация такого типа обычно не выходит за пределы вяоской свиты, но в пределах свиты пересекает первичную слонстость вертикально на несколько метров, что показывает его вторичную природу. В непосредственной близости к наиболее ранним трещинам доломитизация отсутствует и там сохранились известняки. Доломитизации не наблюдается под влиянием свободно циркулирующих подземных вод вблизи трещин и поверхностей напластования. Благоприятным для процесса доломитизации является передвижение той самой подземной воды в капиллярных условиях. Источником магния можно считать реликтовые морские воды из терригенных пород нижнего ордовика.

II тип содержит минерал доломит с идеальной кристаллической структурой. Эти породы четко связаны с тектоническими трещинами. Доломитизированы и породы выше- и нижележащих горизонтов. Агентом доломитизации можно предполагать подземные воды, которые несколько нагревались при перемешивании с гидротермальными флюидами.

\section{ЛИТЕРА Т У Р А}

Вахер Р., Пуура В., Эрисалу Э. О тектоническом строении Северо-Восточной Эстонии. - Тр. Ин-та геол. АН ЭССР, 1961, 10, 319-335.

Вингисаар П., Таалманн В. Обзор доломитизации нижнепалеозойских карбонатных

пород Эстонин. - Изв. АН ЭстССР. Хим. Геол.; 1974, 23, 237-243.
Вингисаар П., Утсал К. О породообразующих карбонатных мннералах палеозоя Эстонии. - Сов. геология, $1978,12,107-115$. Вишняков С. Г. Генетические типы доломитовых пород северо-западной окраины Рус-
ской платформы. - В кн.: Типы доломитовых пород и их генезис. Тр. Геол. ин-та АН СССР, вып. 4, 1956, 209-255.

Перенс Р. О применении расходометрии при расчленении гидрогеологического разреза карбонатной толщи на Пандивереской возвышенности. - Изв. АН Эст. ССР.
Геол., 1978, 27, 130-139.

Пичугин М. С., Пуура В. А., Вингисаар П. А., Эрисалу Э. К. Региональные проявления 
метасоматической доломитизации в связи с тектоническими нарушениями в нижнепалеозойских отложениях Северной Прибалтикн. - Сов. геология, 1976 , $10,78-90$.

Решения межведомственного регионального стратиграфического совещания по разработке унифицированных стратиграфических схем Прибалтики 1976 г. Ленинград, 1978.

Страхов Н. М. О типах и генезисе доломитовых пород (состояние знаний). - В кн.: Типы доломитовых пород и их генезис. Тр. геол. ин-та АН СССР, вып, 4, 1956, $5-27$.

Судов Б. А. Свинцово-цинковые рудопроявления на территории Эстонской ССР и их перспективы. - Разведка и охрана недр, 1973, 3, 16-19.

Borch, von der, $C$. The distribution and preliminary geochemistry of modern carbonate sediments of the Coorong area, South Australia. - Geochim. et Cosmochim. Acta, 1965, 29, 781-799.

Folk, L. R., Land, L. S. Mg/Ca ratio and salinity: two controls over crystallization of dolomite. - Amer. Assoc. Petrol., Geol. Bull., 1975, 59, 60-68.

Lovering, T.S. The origin of hydrothermal and low temperature dolomite. - Econ. Geol., 1969, 64, 743-754.

Möls, E. Eesti aluspõhja lõhede geneesist. - ENSV TA LUS. Geoloogiline kogumik. Tartu, 1961, 1, 5-15.

Niin, M., Niin, S., Puura, V., Taalmann, V. Lōhetäidetest Tallinna ümbruse paemurdudes. - ENSV TA LUS. Settekivimid ja tektoonika. Tallinn, 1981, 113-125.

Orviku, K. Lithologie der Tallinna-Serie (Ordovizium, Estland) I. Tartu, 1940.

Usdowski, H. E. The formation of dolomite in sediments. - In: Recent Developments in Carbonate Sedimentology in Central Europe. Berlin-Heidelberg-New York, 1968, 21-32.

Управление геологии Эстонской ССР
Поступила в редакцию 21/VI 1982

\section{T. KIIPLI}

\section{DOLOMIIDID KESKORDOVIITSIUMI VÄO KIHISTUS}

Väo kihistus on eristatud kaht tüüpi sekundaarseid dolomiite, kirjeldatud nende levikut vertikaalselt ja pindalaliselt, keemilist koostist ja mineraali kristallivōre omadusi.

Kaltsiumirikkad laienenud kristallivōrega dolomiidid paiknevad põhiliselt väo kihistus $\mathrm{ja}$ on tõenäoliselt moodustunud alamordoviitsiumi terrigeensetest kivimitest pärineva reliktse merevee mõjul. Ideaalstruktuuriga dolomiite leidub peale väo kihistu ka alumistes ning ülemistes lademetes. Nende teke on tõenäoliselt seotud põhjavee mõjuga, mille temperatuur on mõnevõrra kõrgenenud hüdrotermidega segunemisel. Artiklis on püütud sekundaarseid protsesse Tallinna ümbruses ajaliselt järjestada.

\section{T. KIIPLI}

\section{DOLOMITES OF THE ESTONIAN MIDDLE ORDOVICIAN VÄO FORMATION}

Two types of dolomites have been distinguished in the Väo Formation. The first one contains Ca-rich mineral dolomite with a deformed crystal structure. It is most common to the Väo Formation and rarely extends beyond it. Dolomitization cuts across the primary bedding to the extent of several metres, which clearly proves the secondary nature of the processes (Figs 2, 3). Near the oldest cracks the process of dolomitization was hindered. About $0.5 \mathrm{~m}$ at both sides of the cracks one can find nondolomitized detritic limestone (Fig. 3A, Photo Table I, photos 1,2$)$. Dolomitization is of widest distribution at $2.5 \mathrm{~m}$ above the base of the Formation, in the lower part of the thick-bedded limestone; that phenomenon may have been caused by the circulation of Mg-rich solutions along the contact zone of rocks of different composition. That type of dolomite is distributed in North-West Estonia and less frequently in other areas (Fig. 1). Dolomitization has probably been caused by the relict marine waters from the Lower Ordovician terrigenous sediments.

The second type of dolomite consists of mineral with an ideal crystal structure. That type of dolomitization is mainly connected with the Pärnu-Narva fault zone (Fig. 1). It usually embraces the whole thickness of the Väo Formation and also extends into the underlying and overlying carbonate rocks. This dolomite has probably been formed by underground waters, heated by their mixing with hydrothermal fluids. 